\title{
土ホコンクリート構造物の設計における 品質の考光方とその例
}

小林 明 夫*

\section{1.はしがき}

土木の分野では, コンクリート構造物を含めて, 構造 物の使用目的は非常に多種類にわたっている。また，大 半が公共の目的に供用されていて, その使用条件, 環境 条件も多様である。構造物が使用目的に応じて長期間供 用されるためには, 計画, 設計, 施工, 保守管理などの 一貫した精度のよい品質が要求され，これらの間には密 接なつながりを必要とする。無理な計画, 目的に適合し ない設計，不良な施工のどれ 1 つを取り上げても，使用 目的から外れ，構造物としての機能を損なう可能性が大 きい。ここでは設計の品質のあり方を述べ，また，国鉄 の構造物の設計管理の基本である設計示方書の変遷につ いて, 次いで設計品質管理のための手順, 施策などにつ いて述べる。

\section{2. 設計における品質}

設計における品質は，その用途，目的に応じて一定の 手法で計算し図面化した成果物が, 計画に適合し, 構造 物の経済性, 施工性, 耐久性, 保守管理, 環境一の適応 性, 美観などを満足することを予想できるものであるこ とが必要である。成果物を得るまでの過程のなかで, 設 計の方法の選択, 施工への対応を考慮したチェック, メ ンテナンスフリーとするための細目など，包含すべき内 容は多い。

\section{1 計画}

広義に解釈して計画も設計の範俦に入るとすれば，個 々の構造物の設計が良好であっても, それを含む計画が 適切でなければ，その設計は正しく評価されないことに なる。構造物の計画の必要が生じた場合, 構造物の構造 型式, 安全性, 機能性について考慮するだけでなく, 経 済性, 施工性など, 総合的な検討が必要である。たとえ

* 正会員 日本国有鉄道構造物設計事務所
ば立体交差工事では, 構造物の種類, 適正な基礎形式と 支持層, 適正なスパン割り, 適正な柱間隔と断面形状な ぞについて, 構造物の安全性, 機能性を検討すると同時 に, 必要な空頭に対してもっとも経済的な構造を検討す る。個々の構造物の工事費が多少高くても，構造物の高 さ（施工基面）を低く抑えれば，アプローチを含めた全 体的な工事費を安くすることができるものである。施工 基面の決定は, 鉄道, 道路のような交通施設では走行安 全, 線形計画に関係する事項であるが, 交差部分の空頭 を最小限に抑えるよう構造形式を検討する必要がある。 ラーメン型式の高架橋では施工基面の高さの総工事費に 与える影響は大きく, 高さが $1 \mathrm{~m}$ 高くなれば 5.5 万〜 6.5 万円 $/ \mathrm{m}$ 程度高くなる。高さが高く版上死荷重も大きい 場合には地震の影響も受けやすく,震度 0.05 大きくなる と平均 5 万円 $/ \mathrm{m}$ 程度高くなるという試算がある。

\section{2 設計手法}

構造物の設計手法については許容応力度法, 終局強度 設計法, 限界状態設計法などがあり, 限界状態設計法に 次第に移行すると考えられている。目的とする構造物に 対してある限界状態の検討をする場合に, 許容応力度を 用いる方がよい場合は許容応力度を用いるのがよく，ど の方法が適切であるかを判断して採用すべきである。国 鉄で今回行った建造物設計標準の改訂にあたっては, 静 的な耐力の検討のためには降伏強度から定まる許容応力 度を, 疲労の検討に対しては活荷重の種類, 頻度ごとに 検討している。また, 柱, 橋脚では, 列車走行の安全性 を損なわない範囲で変形を許容する場合には終局強度設 計法も取り入れている。

\section{3 設 計計算}

設計計算上の仮定, 材料の特性などは, 基本的には土 木学会「コンクリート標準示方書」に準拠している。し かし, 構造物の使用目的によって鉄道, 道路など多種類 にわたっているため，目的別にさらに実践的な示方書の 
類 (国鉄では建造物設計標準, 道路関係では道路橋示方 書など) が制定されている。設計計算の目的は, 目的と する構造物が必要な強度, 安定性, 安全性, 耐久性をも つことを明らかにするむのであるが，単に経済的な断面 とするための応力チェックだけで計算を終了させるので はなく, 交通の走行安全性, たわみ, 隣接構造物との目 違い, 折れ角などの検討, あるいは地震時の変形, 破壞 に対する検討によって，それぞれを満足することを確認 することが必要である。

通常の形状の構造物では, 計算上の仮定は慣行の方法 で行えばよいが, 異形の, あるいは複雑な構造物に対し ては, どうしても設計者の判断により仮定しなければな らない場合がある。高度な解析を行う場合など, 仮定の 立て方によって, いちじるしく異なる応力の傾向, 数值 がアウトプットされ, 判断に迷うこともある。合理的, 経済的な設計のために行う解析の結果, 部分的に過大な 応力がでてくることについては, やはり熟練者と協議す べきであろう。

許容応力度に対する計算応力度の関倸は, 当然, 許容 応力度に近い計算值とするのが望ましい, そのような断 面寸法を選ぶベきであって, そのために何回かのトライ アルを必要とする。しかし, 許容応力度に対してかなり 余裕のある設計もしばしば見受けられるので, 断面縮 少, 鉄筋量減少の検討を行うことが必要である。

しかし, 構造形式によっては, このようなことが画一 的に行われにくい場合もある。たとえば, 線路方向, 線 路直角方向とも多径間のラーメン高架橋では, はり, 柱 の応力度は, 許容応力度に対して余裕がある場合もでて くる。柱, はり1本ごとに断面または鉄筋量（本数, 直 径）を変化させることは実際の施工では施工ミスの誘因 ともなることを考えれば, 工事を正確に施工するために は, 断面, 鉄筋量の種類は少ない方がよいと考えられ る。

また，ゲルバーけた受け部分のような箇所では，計算 方法にも設計者の判断が入り, 安全側に考えて鉄筋量は 多くなりがちである。したがって, 配筋が密なためにコ ンクリートの打込みに不安あるということも側聞してお り，やはり施工も念頭においた設計をすべきものと考え る。

このように，経済的設計と施工を考えた設計とは一見 矛盾する内容を含むことがあるが，設計図面に表現され た内容と出来上がった構造物の品質との関連を常に考慮 して設計すべきである。

\section{3. 国鉄の設計示方書の変遷}

鉄道構造物としては, 当初, 石積, れんが積橋脚など が多く建設されたが，明治末ごろからコンクリート構造
物が出現し, 各地に普及した。その数も増加していった が，設計・施工が技術者個人の裁量にまかされていて危 険でもあり，不統一でもあったので，設計・施工の基準 ならびに標準設計図の判定が要望され，昭和 42 年に外 国の示方書を範として，わが国で初めての鉄筋コンクリ 一ト設計・施工の示方書案をつくった。これらを基礎と して, 大正 3 年には「鉄筋コンクリート橋梁設計心得」 が制定された。

その内容は, 荷重, 許容応力度, 各部設計, 設計細 目，材料，施工方法，型わく，アーチセントルなど, 設 計ならびに施工に関する事項にまで及んでいる。

動荷重は, 甲種荷重 (E 45, KS-20), Z 種荷重 (E 40, KS-18）の 2 種類としている（のちに改正され，E-40, E-33 (KS-15) となった)。このほか, 衝撃何重, 横荷 重 (列車荷重, 列車風圧), 縱荷重 (制動荷重), 離心力 (遠心力), 温度变化による影響などを規定している。

なお許容応力度は, 配合 $1: 2: 4$ を標準として曲げ圧 縮応力が $600 \sharp / \square^{\prime \prime}\left(40 \mathrm{~kg} / \mathrm{cm}^{2}\right)$, 鉄筋は $1050 \mathrm{~kg} / \mathrm{cm}^{2}$ である。地震については，この時代は規定はまだなかっ た。

設計要項としては，連続ばりなどの不静定構造に対す る応力計算方法その他が記されている。また細目では, スラブの最小厚, 鉄笳間隔, かぶり, 定着長, 鉄筋の継 手，防水などがある。

またこの際, 設計心得にもとづいて標準設計を企画し た。橋台, 橋脚に対しては地震荷重（前記心得には規定 はない), 衝撃, 制動荷重を考慮した, 当時としては進 歩的な内容のものであった。標準設計の内容は, 半卵形 混凝土拱橋標準図, 鉄筋混凝土函渠標準, 混凝土井筒定 規 (楕円形), 停車場構内地下道標準図などであった。

ついで昭和 6 年, 土木学会の最初の「鉄筋コンクリー 卜標準示方書」が制定された際，この標準示方書に準拠 した標準設計図集が刊行された。土木学会の標準示方書 には, コンクリートの設計強度, 死活荷重, 地震加速度 (水平: $0.2 \mathrm{~g}$, 垂直 : $0.1 \mathrm{~g}$ ), 温度変化, 硬化収縮の影 響, 弹性係数比, 許容応力度, 細目など, ほぼ今日の示 方書の骨格を形づくっており, ついで昭和 11 年, 15 年 に第 1 次, 第 2 次改訂が行われたが, 国鉄の標準設計も 事実上これにならうこととなった。

標準図は，橋台，橋脚，鉄筋コンクリート ( R C ) 版, R C T げた, 単径間ラーメン函渠, 2 径間連続函渠など で, 活荷重は, 前回の標準設計では E 40(KS-18), E 33 （KS-15）の 2 種類であったのに加えて, KS-12, KS-10 など，丙線以下にも適用可能なものとした。橋脚は，円 形, 棈円形, 矩形の 3 種類となり, 鉄筋コンクリートげ たの標準スパンに合わせた多種類のものとなった。 R C 単 Tげたではコンクリート許容圧縮応力度 $50 \mathrm{~kg} / \mathrm{cm}^{2}$ と 
し, スパンも 4.5 11.7 $\mathrm{m}$ の 8 種類, 単版げたは 11 種 類となっている。

昭和 31 年には土木学会「無筋・鉄筋コンクリート標 準示方書」が, 36 年には「プレストレストコンクリー 卜設計施工指針」が制定された。国鉄では「無筋および 鉄筋コンクリート構造物の設計基準（案）第 1 編（昭和 30 年)」,「同第 2 編（同 33 年)」, P Cげたについては 「プレストレスト鉄道橋設計施工基準 (案) 設計編施工編 (昭和 40 年)」を定めたが, 昭和 41 年, 国鉄部内の規 程類見直しの際に「建造物設計基準規程」を定め, 以降 の設計基準類はすべてこれに準拠することとなった。新 幹線については, 昭和 41 年に「新幹線建造物設計基準 規程」を定めた。

この時代の標準設計としては，R C 版げたは KS-18, $\mathrm{KS}-16$ とも 18 種類 (斜角を含む), KS-14 が 5 種類, R C T形げたは KS-18，16 とも各 24 種類(斜角を含 む)，KS-14 が 8 種類， R C 箱げたは KS-18, 16 とも 4 種類, $\mathrm{H}$ 形鋼埋込みげた, $\mathrm{KS}-18,16$ とも 5 種類, $\mathrm{P} \mathrm{C}$ げた（標準的けた高, けた高制限, けた高増を含む）は $\mathrm{KS}-18$ が 28 種類 (斜角を含む)，KS-16 が 24 種類 (斜角を含む)，KS-14 が 6 種類， P C下路げたは KS18,16 とも 5 種類, R C 高架橋 (単線 2 柱式, はり出し 形式, 複線 2 柱式はり出し式, ゲルバー形式, 背割形 式）等, その他カルバート, 土留擁壁, 控え壁式など, 多種類に及んでいる。

その後, 昭和 42 年土木学会「コンクリート標準示方 書」の改訂にともない，国鉄においても「建造物設計基
準規程」の改訂とともに，昭和 45 年に R C と P C を 「設計標準」として統一した。これらの標準設計は，線 路増設工事, 改良工事に多用されている。

新幹線においては, 昭和 39 年に「東海道新幹線鉄道 構造規程」を, 43 年に「新幹線建造物設計基準規程」 を定め, 設計はすべてこれに準拠している。新幹線は, 東海道, 山陽，東北（上越）と時代を下るに従って標準 設計の種類も増加し, 東北の場合は R C版げた 9 種類, R C T形げた 23 種類, R C 箱形げた 18 種類, $\mathrm{H}$ 形鋼 埋込みげた 6 種類, R C I 形げた 50 種類, P C 箱形げ た 7 種類，高架橋 78 種類など， 181 種類のけたを設計 している。

P Cげたについて, 東北 (上越) 新幹線の特長は, 軌 道スラブ（長さ $5 \mathrm{~m}$ ） の整数倍に対してけた長を定めて いるが，現地の立地条件によっては端数の長さとの組合 せとなるので，標準設計に対して $\pm 1 \sim 3 \mathrm{~m}$ の範囲で P C 鋼材の增減, 緊張力の増減によって対応できるよう 標準設計の適用の拡大をはかったことである。新幹線 は，ほとんどが標準設計と，その適用拡大された設計を 使用している。

昭和 58 年 2 月には, 52 年の土木学会「コンクリート 標準示方書」, 53 年の「プレストレストコンクリート標 準示方書」の改訂に合わせて，また国鉄の R C , P C 設 計標準も 10 年を経過したので，その内容の見直しをは かるとともに, 最近の研究成果を取り入れて改訂を行っ た。

図一1 に，現行の設計に関する諸規程の体系を示す。

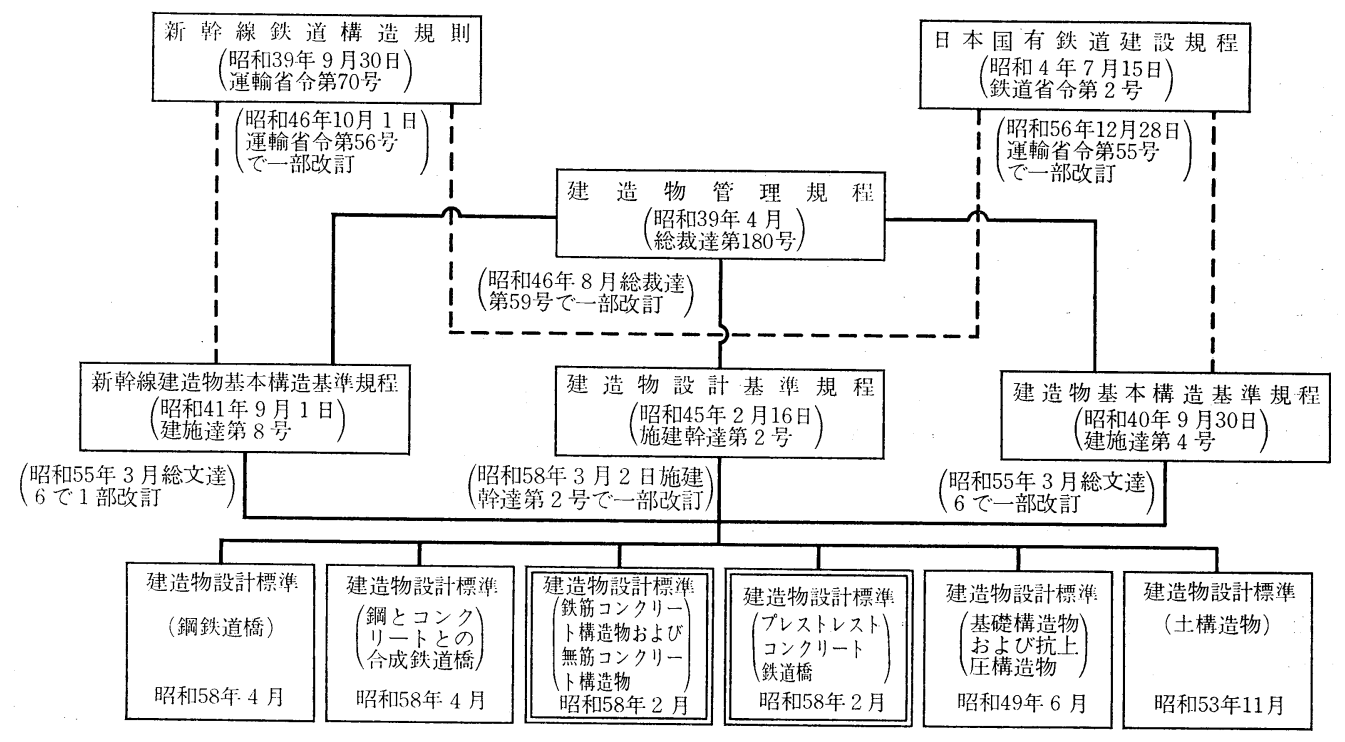

注）1. 破線は法令との関係を実線は部内規程・

2.一部改訂は最終改訂年月を示す(昭和58年 1 月現在) 標準との関係を示す。 


\section{4. 国鉄におる設計の品質管理の具体的方法}

設計の品質を高めるためには，統一した設計方法に従 い，類似の既設計との対照・比較，および設計の途中段 階でのチェックも行いながら進めていく必要がある。

国鉄でも，他機関と同様化設計の外注化が多く行われ ている。全国にわたって行われる各種改良工事，連続立 体交差工事等に関連した設計業務は，ほとんどがコンサ ルタンツに委託されているのが実情である。

そこで，国鉄で行われている設計の品質および設計管 理の方法について次に述べるが，これらは互いに独立で なく, 1 つの設計計画から設計完了までの過程で大きな 関連をもつものである。

\section{1 審查」および「指導」}

設計には汎用性のある標準設計と，1つのプロジェク 卜の過程で必要となる構造物の設計の 2 種類があり, 後 者はさらに, 特殊な構造または特殊な施工法を必要とす る構造と, 標準設計に類似していて若干の構造変更（た とえばスパンなど）で設計可能なものなどが市る。国鉄 では，プロジェクトの設計内容によって，構造物ごとに 「審査」扔よび「指導」の 2 通りに区分けして設計業務 に対応している。

「審查」は，施工局がコンサルタンッに外注した設計 について構造物設計事務所がその成果物の審查を行うむ ので, また「指導」は, 施工局が外注した成果物を審查 するにあたって, その主要点を構造物設計事務所が指導 する場合をいう。

「審査」の場合は，審查員を指定して 直接担当させる ことになっている。

また, 標準設計に近いものは「審査」「指導」の対象 外としている。このような「審査」「指導」の区分はコ ンクリート構造物だけでなく鋼構造物, 基礎構造物など 他の部門にもあるが，ここではコンクリート構造物につ いて 表一1 に示す。「審査」「指導」の作業手順を 表一 2, 3 に示す。

\section{(1)「審査」作業}

プロジェクトが計画された場合に，(A)の打合せに抒 いて調査データ, 構造計画, 工期, 発注計画などを検討 し, 上部構造, けた型式, 下部構造, 基礎型式等の経済 性, 施工性, 維持管理, 環境の適応性などの検討を行 い, 問題点を抽出し, 検討事項の整理を行う。また, そ の過程で構造型式が決まれば, 構造物の材料選定 (コン クリート構造物か鋼構造物か) も必然的に行われる。こ の際に, (B) に扔いて, 該当設計が「審査」事項か「指 導」事項かを決定する。

設計を発注したのち，(C)においては，(A)での検討内 容, 指示事項の確認とともに設計方針に関するデータ,
施工条件などを検討して概略設計を行い，スケルトンを つくり, 詳細設計に入ることになる。詳細設計では, 荷 重条件, 地盤条件, 解析方法, 主要部材寸法, その他設 計上の諸事項を検討しながら進め, (D) において (A)から の検討, 指示事項, 設計条件の確認を行い, 構造物の設 計上, 施工上, 保守上の問題点をチェックしながら, 設 計作業の過程で修正があった場合には, 指摘事項の修正 済みを確認したのち, 原図全葉に関係者がサインを行 亏。

\section{(2)「指導」作業}

(P) において (A)での検討指示事項を確認し, 設計方針 に関するデータおよび施工方法の検討を行う。(G) にお

表一1「審査」, 「指導」の区分

\begin{tabular}{|c|c|c|c|c|}
\hline \multicolumn{2}{|c|}{ 区ー 区 分 } & 查 & 指 & $\begin{array}{l}\text { 審查·指 } \\
\text { 導対象外 }\end{array}$ \\
\hline $\begin{array}{l}コ \\
\text { ン } \\
\text { ク }\end{array}$ & $\mathrm{RC}$ & $\begin{array}{l}\text { 標準設計げた，アー } \\
\text { チ，異径間長大スパン } \\
\text { のラーメン }\end{array}$ & $\begin{array}{l}\text { 斜角 } 45^{\circ} \text { 以下のけた, } \\
\text { 軟弱地盤上の高架橋, } \\
\text { 施工順序の複雑な構 } \\
\text { 造, 駅部高架橋, その } \\
\text { 他特殊な構造 }\end{array}$ & $\begin{array}{l}\text { 標淉設計 } \\
\text { に近いも } \\
\text { の }\end{array}$ \\
\hline $\begin{array}{l}1 \\
1 \\
1\end{array}$ & $\mathrm{PC}$ & $\begin{array}{l}\text { 標準設計げた, 不静定 } \\
\text { 構造, 連続げた, 長大 } \\
\text { スパンげた }(l \geqq 250 \\
\mathrm{m}), \text { 特殊な 施工法, } \\
\text { 特殊な構造 }\end{array}$ & $\begin{array}{l}\text { 斜角のきついけた，け } \\
\text { た高制限のきついけた } \\
(h \leqq 1 / 18 \cdot l) \text {, 下路, } \\
\text { ホローおよひプレキャ } \\
\text { ストけた }\end{array}$ & $\begin{array}{l}\text { 標準設計 } \\
\text { に近いむ } \\
の\end{array}$ \\
\hline
\end{tabular}

表一2「謇査」の手順

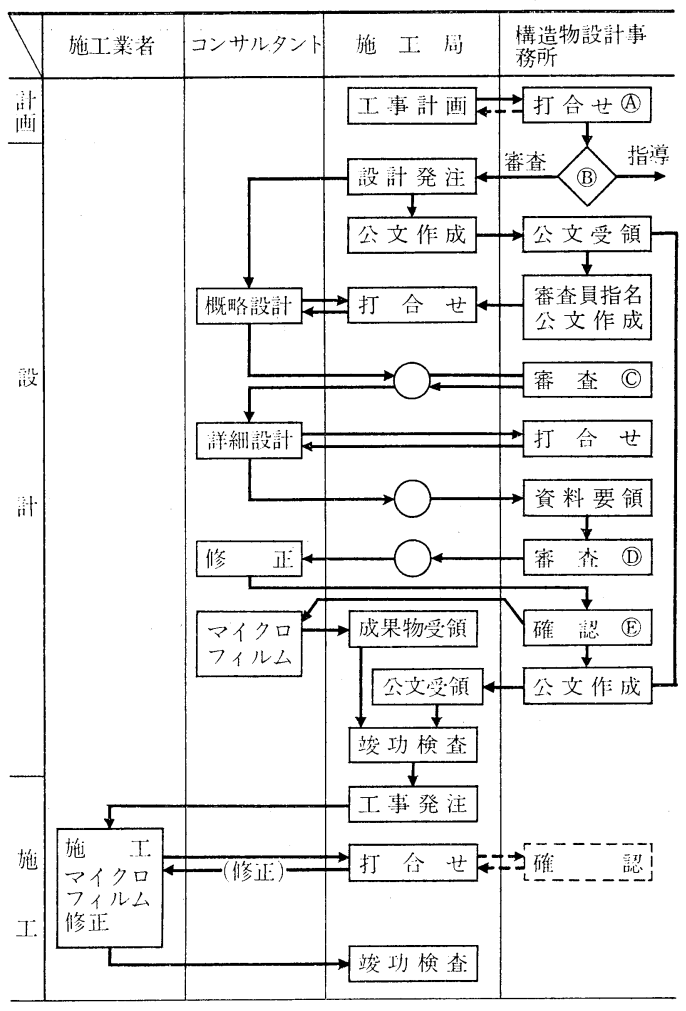

○印は必要を生じな莂合連絡打合せを行うことを示す。 
表一3「指導」の手順

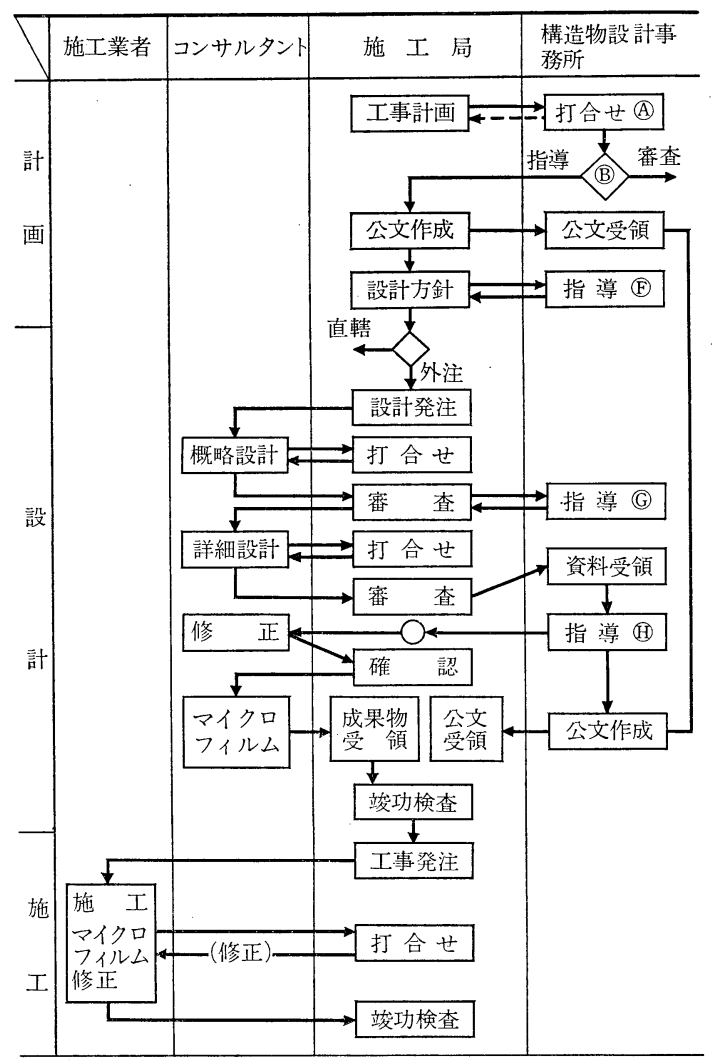

○印は必要を生じた場合連絡打合せを行うことを示す。

いては施工局の審查事項に対して検討し，設計条件およ び施工条件の確認を行い, (H) において最終的に検討デ 一タの確認整理を行う。施工局では, (1) での指示, 修 正事項などがコンサルタンツからの図面に指示どおり修 正されていることを確認して設計終了とする。

設計成果物に対しては，「審査」作業では構造物設計 事務所の審査員は設計計算書, 設計図を対象として審査 するが，「指導」作業では，施工局の審査に対して構造 物設計事務所は主として設計上の仮定などの設計条件, また設計図では配筋図などを対象とする。

最近のように電算が発達すると, 設計条件をインプッ トすれば，インプットデータが間違ってさえいなければ 同様な計算結果を得ることができるので, 計算結果のチ エックに労力をかけるよりも，プロジェクトを必要とす る立地条件, 環境条件, 経済性, 機能性, 施工性, 保守 管理などを含めた全体的な検討を詳細に行って，設計の 成果物としては，設計上の仮定，構造細目などを含めて 設計図面のチェックを行うのが実情に合うものと考えら れる。

4.2 設計手順, チェックリスト
構造物を設計するうえで, 設計の手順, 標準設計図の 設計断面諸元, 材料表などを示すことは, その構造物の 概略形状を念頭におき, 不安定な構造物とならず，しか も経済的な設計を進めるうえで大いに役立つことであ る。国鉄では, 設計のチェックリストとして, R C 構 造, P C 構造, 鋼構造, 土留擁壁等の基礎構造につい て，冊子として配布している。これには構造物全体の設 計手順および部分の設計手順が示されている。また，慣 用の設計手法も併記されている。図一2 の一般的な設計手順の 1 例として単 Tげたの例を示す。

単Tげたのチェックリストには, 断面形状として標準 設計の形状寸法一覧表を記載しているので大まかな形状 寸法を予想することができ，同時に，片持スラブ，中間 スラブ, 主ばりなど，計算順序に従って各項目別に検討 事項を掲げ, 注意事項, 設計標準のなかの参考事項を示 している。さらに, スパン, けた長, けた高に対するコ ンクリート, 鉄筋, 型わくの数量を示し, 妥当な設計か どうかの判断をするのに役立っている。

\section{5. 情報検索システムの利用}

プロジェクトの設計をすべて新規からスタートさせる ことは，外注設計費用が膨大なものとなり，不経済であ る。そこで国鉄では，情報検索 システムを採用してい る。これは, 全国の構造物の設計件名を一箇所に集積 し, 情報を提供する場合は文字のデータとし, データを 必要とする者は，そのデータが使用できるか否を検討 し，さらに詳細なデータが必要である場合は，保管され ているマイクロフィルムから複写して図面などを提供で きるものである。目的とする構造物と設計条件が同一 で, 構造寸法形状が同一のものが蓄積されていればその まま利用できるが，スパンの多少の差などのわずかな構 造寸法の差では類推して適用できるものである。昭和 56 年度までの蓄積データは, R C た 1600 件, P C げた 1294 件, ラーメン式高架橋 2134 件, ラーメン型 式のカルバート 425 件, 土留擁壁 514 件などとなってい る。その他, 鋼橋, 合成げた, 橋台, 橋脚等を合計する と約 1 万 2360 件, 情報検索利用件数は約 1 万 3200 件 となっている。データ蓄積と検索利用を年度別に示せば 図一3 のようになる。また, 表一4 に情報検索の構造物 別利用件数を示すが, その利用率はかなり高く, 全構造 物で 107\%，コンクリート構造物関係で $121 \%$ 程度とな っている。

蓄積データとしては, 設計データと施工データとがあ る。

設計データとしては, 荷重条件, 線路数・軌道半径・ 軌道種別などの使用条件，けた長，スパン・斜角などの 形状寸法, コンクリート・鉄筋・P C 鋼材など材料の使 

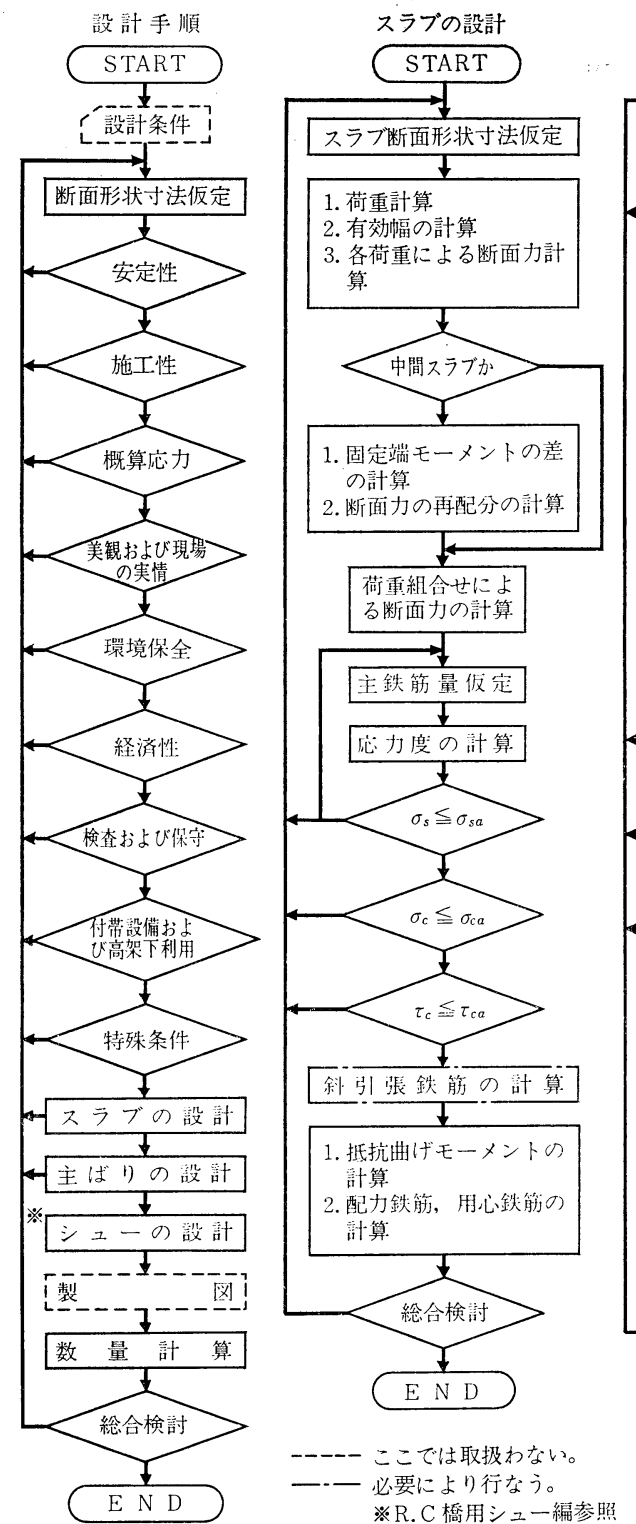

図一2 単 $\mathbf{T}$ げたの設計手順

表-4 情報検索の構造物別利用件数

（昭和 57 年 3 月現在）

\begin{tabular}{|c|c|c|c|c|c|}
\hline \multirow[b]{2}{*}{ 構 造種 別 } & \multirow[b]{2}{*}{$\begin{array}{l}\text { 蓄積 } \\
\text { デー夕数 }\end{array}$} & \multirow[b]{2}{*}{$\begin{array}{l}\text { 利用件数 } \\
\text { (A) }\end{array}$} & \multicolumn{2}{|l|}{ 回 } & \multirow{2}{*}{$\begin{array}{c}\begin{array}{c}\text { 回答 } \\
(\%) \\
(\mathrm{B})+(\mathrm{C})\end{array} \\
(\mathrm{A})\end{array}$} \\
\hline & & & $\begin{array}{l}\text { 出 橉 } \\
\text { した好 } \\
\text { (B) }\end{array}$ & 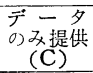 & \\
\hline $\begin{array}{l}\text { コンクリート } \\
\text { イを(RC, } \\
\text { PC橋とも) }\end{array}$ & 2894 & 3718 & 2157 & 262 & 65 \\
\hline 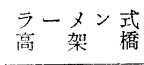 & 2134 & 1301 & 560 & 84 & 50 \\
\hline $\begin{array}{l}\text { ラーメン型式 } \\
\text { カルバート }\end{array}$ & 425 & 1557 & 928 & 84 & 65 \\
\hline 土留濰 壁 & 514 & 660 & 428 & 25 & 69 \\
\hline
\end{tabular}

注）蓄積デー夕の件数は設計データであり，これ以外に施エデー夕がは 票同件数用意されている。

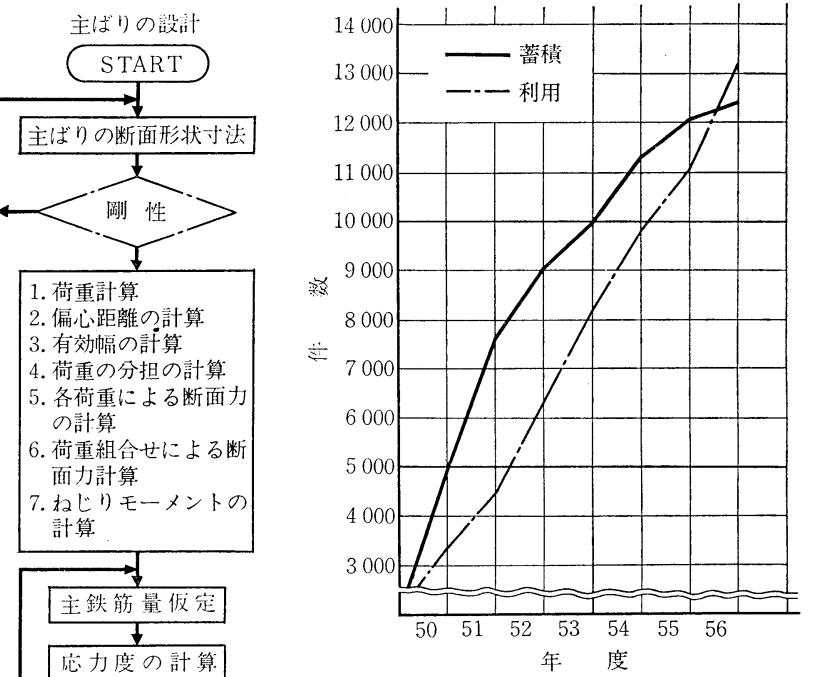

図一3 情報検索の蓄積と利用の年度別累計 (昭和 57 年 3 月)

用数量, 支承種別, 橋側歩道の種類などで ある。また設計時の制約条件としては，け た高制限，けた高自由(経済的けた高)，支 点変位の影響を考慮しているかどうか, 衝 突荷重, 円曲線軌道を支持する直げた（曲 線げた)，動的解析を行ったけた，電車線 荷重を考慮したけた，けたのずれ止め特殊 シュー，水平シューの有無などとなってい る。

施工データとしては, 竣功年月, 施工局 所, 駅間キ口程, 橋りょう名, 架設箇所 (鉄道上か道路上か河川上か)，橋りょう延 長，架設連数などのほかに，制約条件とし て考慮した事項として，何らかの施工上の 制限 (騒音防止等), 美観, 寒冷地带, 単 線げたで橋側歩道が両側にあるかどうか, ガードレールの有無, 単線げたの並列架設 などがある。 P Cげたでは P C 鋼材の定着 工法別, 架設工法では 総足場式, エレクションガーダ 一, 操重車による方法, 移動ベントによる縦移動または 横移動，ポンツーン方式，クレーン架設，はね出し架 設, プレキャストブロックによる方法，その他特記すべ き事項などとなっている。

\section{6.「通達」,「事務連絡」など}

設計の考え方の変更または統一など，その内容をその 都度関係者に通知することは，考え方の混乱を避けるた めに大事なことである。また，材料の進歩を設計に取り 入れたり，施工方法，技術の進歩を設計内容に反映させ 
るなど, 設計との関連は多い。技術の進歩, 砳究の成果 を取り入れ合理的な設計をすることは，経済的な設計を するうえで重要なことである。

国鉄では，設計・施工上の考え方の変更または統一事 項を, その内容によって「通達」「事務連絡」の形で部 内関係各所に連絡している。これは機会あるごとに行っ ており，統一した考え方に従った設計が可能である。最 近では, ゴムシューの適用拡大にあたって, 試験結果を 取り入れた「コンクリート鉄道橋ゴムシューの設計施工 の手引き」を，また P Cげたでは，最近の材料，施工技 術の進歩などによってけた高同一の場合には主げた本数 の低減が可能となるので，P C げた標準設計図集の適用
方法の変更について事務連絡を出している。

\section{7.あとがき}

設計は, 多くの研究成果からその設計方法が変わりつ つあり, 解析も高度な内容となる傾向にある。また構造 物も, 経済的につくることを要求されるため, 設計とし てはかなりシビアなものになりつつある。大半が公共物 である土木構造物では, 長期間の供用のために単なる設 計図までの設計だけではなく, 計画から施工, 保守管理 までを含めた全体の品質のなかでの設計の品質を高める ような管理をすることが大切であると思われる。

\title{
【図書 案 内】
}

\section{コンクリートのひびわれ調査・補修指針 付 : ひびわれの調査と補修事例}

\author{
A 5 判 · 約 270 頁 ·定価 3900 円 (会員特価 3500 円) ·送料 300 円
}

コンクリート構造物に生ずるひびわれは, 構造物の耐力・耐久性・水密性などの諸性能を低下さ せる大きな要因であり，その対策の重要性はいまさら述べるまでもない。

本指針は, 日本コンクリート工学協会ひびわれ調查研究委員会が, 昭和 50 年より今日まで行っ てきた研究成果を基に作成したものであり, 構造物に発生したひびわれに対して, 補修を要するか 否か, またどのような補修工法を採用すべきかの判断資料を得るための調查方法と, 補修技術の基 本的な考え方と手順を示したものである。

本書はまた, 本文及びその内容を具体的に詳述した解説に加え, その運用の参考として各種構造 物 27 件の補修事例を取り上げ，わかりやすい，また親しみやすい技術参考書的構成とした。

1 童 総則

1.1 適用範囲

1.2 調查および補修の手順

2 章調查

2.1 総 則

2.2 標準調查

2.3 詳細調查

3 章 原因推定

3.1 総 則

3.2 標準調查に基ゔく原因推定

3.3 詳細調查に基づく原因推定

4 章 補修の要否の判定

4.1 総 則

[目次]

\section{2 調查結果に基づく判定 \\ 4.3 技術者の高度な判断に基つく判定 \\ 5 章補修方法}

5.1 総 則

5.2 補修設計

5.3 補修工法

5.4 補修材料

5.5 補修の検査および確認

付 : ひびわれの調查と補修事例

共同住宅 5 例, 事務衣 5 例, 工場 - 倉庫 3 例, 公共建築等 3 例, 煙突 1 例, サイロ 1 例, 橋り 上5・橋脚 3 例, トンネル 1 例, ダム 1 例, 浄 水場 2 例, 港湾構造物 1 例, 舗装 1 例

○申込先 : (社)日本コンクリート工学協会

干 102 千代田区敖町 5-7 TBR ビル 708 号 電話 東京 (03) 263-1571

※注文は書名，送付先を明記の上，前金にてお申込み下さい。 